\title{
Exports and Economic Growth: Some Evidence from the GCC
}

\section{Athanasia Stylianou Kalaitzi ${ }^{1,2}$ (D) Trevor W. Chamberlain $^{3}$}

\section{JELs $\mathrm{F} 10 \cdot 040$}

A number of studies have identified the positive effect of exports on economic growth (export-led growth (ELG) hypothesis) through enhanced economies of scale, adoption of advanced technology and greater capacity utilization (Feder, Journal of Development Economics, 1982; Lucas, Journal of Monetary Economics, 1988; Al-Yousif, Applied Economics, 1997; Vohra, International Advances in Economic Research, 2001; Abou-Stait, Economic Research Working Paper Series, 2005). In particular, export growth increases investment in those sectors in which a country has a comparative advantage, increasing national output and raising the rate of economic growth. An increase in exports also increases the inflow of foreign exchange, and permits the expansion of imports of services and capital goods, which are important in increasing productivity and economic growth.

In contrast, other studies have found that exports have a negative impact on economic growth, noting that this effect is associated with primary goods comprising a large share of total exports in some countries (Lee and Huang, Journal of Economic Development, 2002; Herzer et al., The Developing Economies, 2006; Kim and Lin, Journal of Development Studies, 2009; Kalaitzi and Cleeve, Eurasian Business Review, 2017). Inasmuch as the Gulf Cooperation Council (GCC)

Electronic supplementary material The online version of this article (https://doi.org/10.1007/s11294-02009786-0) contains supplementary material, which is available to authorized users.

Athanasia Stylianou Kalaitzi

a.kalaitzi@1se.ac.uk

1 London School of Economics and Political Science, Middle East Centre, WC2A 2AZ, London, UK

2 Queen Mary University of London, School of Business and Management, Mile End Campus, E1 4NS, London, UK

3 DeGroote School of Business, McMaster University, 1280 Main Street West, Hamilton, Ontario L8S 4M4, Canada 
countries are natural-resource-abundant countries and have experienced significant economic growth since the early 1970's, this study investigates whether exports are the cause of this growth. The study contributes to the current discourse on the design of future policies to enhance and sustain growth in the GCC and offers a framework for examining the relationship between exports and growth in other countries that rely heavily on natural resources as a source of export earnings.

The study investigates the validity of the ELG hypothesis for five GCC countries: Bahrain, Kuwait, Oman, Saudi Arabia and the United Arab Emirates (UAE). Aggregate output for each country is expressed as a function of physical capital, human capital, exports and imports. The data used in the study, covering the period 1975-2016, were obtained from the World Development Indicators (World Bank 2019) and International Financial Statistics (International Monetary Fund 2019). Gross domestic product (GDP) was used as a proxy for economic growth, gross fixed capital formation as a proxy for physical capital, population (15-64) as a proxy for human capital, and merchandise exports and imports of goods and services as proxies for exports and imports, respectively. Using the World Bank GDP deflators, the data were expressed in real terms, and utilized logarithmic form.

The Johansen cointegration technique was applied to confirm the existence of a long-run relationship between exports and economic growth. The multivariate Granger causality test was used to examine the direction of short-run causality. The existence of long-run causality was investigated using a modified version of the Wald test in an augmented vector autoregressive model framework (Toda and Yamamoto, Journal of Econometrics, 1995). The null hypothesis that exports do not cause economic growth was tested against the alternate hypothesis that exports do cause economic growth. In addition, the null hypothesis that economic growth does not cause exports was tested against the alternate hypothesis that economic growth does cause exports (the growth leads exports (GLE) hypothesis).

Cointegration test statistics indicate that the hypothesis of no cointegration is rejected $(p<0.05)$ for all countries except Oman $(p=0.30)$. Short-run causality results show that the null hypothesis of no causality from exports to growth is rejected for Kuwait $(p=0.09)$ and the UAE $(p=0.04)$, indicating that the ELG hypothesis is valid for these countries. In addition, the null hypothesis of no causality from economic growth to exports (GLE hypothesis) is rejected for Bahrain $(p=0.06)$ and Kuwait $(p=$ 0.03 ). Thus, for Kuwait, bi-directional causality is indicated. ${ }^{1}$ No evidence of short-run causality in either direction is indicated for Oman and Saudi Arabia nor, for these two countries, is there evidence of indirect causality from exports to growth through physical capital, human capital or imports.

For long-run causality, the null hypothesis that exports do not Granger cause economic growth cannot be rejected for any country except Bahrain $(p=0.03)$. However, the evidence supports the converse for Kuwait and Saudi Arabia. The null hypothesis that growth does not cause exports can be rejected $(p=0.06)$, and $(p=0.01)$, respectively, for these countries. In addition, indirect causality runs from exports to growth through imports and physical capital for Kuwait.

\footnotetext{
${ }^{1}$ Tables 1 and 2 in the Online Supplemental Appendix report the results for short-run and long-run causality in Kuwait.
} 
The study's findings should be of interest to policy makers in the GCC as their countries move away from dependence on fuel exports and devise economic development strategies in keeping with their 2016 pledges to the United Nations' 2030 Agenda for Sustainable Development. ${ }^{2}$ Future research should focus on export categories in an effort to determine whether the relationships between disaggregated exports and economic growth mirror the relationships observed at the aggregate level.

Open Access This article is licensed under a Creative Commons Attribution 4.0 International License, which permits use, sharing, adaptation, distribution and reproduction in any medium or format, as long as you give appropriate credit to the original author(s) and the source, provide a link to the Creative Commons licence, and indicate if changes were made. The images or other third party material in this article are included in the article's Creative Commons licence, unless indicated otherwise in a credit line to the material. If material is not included in the article's Creative Commons licence and your intended use is not permitted by statutory regulation or exceeds the permitted use, you will need to obtain permission directly from the copyright holder. To view a copy of this licence, visit http://creativecommons.org/licenses/by/4.0/.

Publisher's Note Springer Nature remains neutral with regard to jurisdictional claims in published maps and institutional affiliations.

\footnotetext{
${ }^{2}$ See Al-Saidi et al., Development in Practice, 2019 for a history of sustainable development in the GCC.
} 